\title{
Molecular analysis of artisanal Italian cheeses reveals Enterococcus italicus sp. nov.
}

\author{
M. Grazia Fortina, G. Ricci, D. Mora and P. L. Manachini \\ Department of Food Science and Microbiology - Industrial Microbiology Section, University of \\ Milan, Via Celoria 2, 20133 Milan, Italy
}

Correspondence

M. Grazia Fortina

grazia.fortina@unimi.it
Enterococci constitute a large proportion of the autochthonous bacteria associated with the mammalian gastrointestinal tract and can cause infection from this endogenous source. The incidence of infections caused by enterococci, together with the increasing difficulty of treating such infections because of multiple antibiotic resistance, put these organisms, especially Enterococcus faecium and Enterococcus faecalis, among the emerging human pathogens (Morrison et al., 1997; Robredo et al., 2000). However, enterococci are ubiquitous and can be found as free-living micro-organisms in soil, on plants and in large numbers in dairy products, where, in some cases, they predominate with respect to lactobacilli and lactococci (Franz et al., 1999; Giraffa, 2002). The presence of enterococci in dairy products has long been considered as an indicator of inadequate sanitary conditions during the production and processing of milk. In contrast, many authors suggest that enterococci may have a potentially desirable role in some cheeses, because of their proteolytic and lipolytic activities, in the development of typical flavours and for the production of enterocins with anti-Listeria activity (Ennahar \& Deschamps, 2000; Giraffa et al., 1997). The important question is whether enterococci originating from food and from community sources possess an equally pathogenic potential, or whether differences in pathogenicity exists, perhaps in relation to the different species. In this context,

\footnotetext{
The GenBank/EMBL/DDBJ accession number for the 16S rRNA gene sequence of Enterococcus italicus TP1.5 ${ }^{\top}$ is AJ582753.

DNA-DNA relatedness values and the long-fatty-acid composition of Enterococcus italicus sp. nov. and other enterococcal species are available as supplementary material in IJSEM Online.
}

correct species identification is of great importance to both medical and food microbiologists.

Since the revival of the genus Enterococcus by Schleifer \& Kilpper-Bälz (1984), phylogenetic studies have established, on the basis of $16 \mathrm{~S}$ rRNA gene sequences, the presence of at least four 'species groups' (Devriese et al., 1993; Devriese \& Pot, 1995; Stiles \& Holzapfel, 1997), as follows: the 'faecium group', comprising Enterococcus faecium, Enterococcus durans, Enterococcus hirae, Enterococcus mundtii and the newly described Enterococcus villorum (Vancanneyt et al., 2001); the 'avium group', comprising Enterococcus avium, Enterococcus raffinosus, Enterococcus malodoratus and Enterococcus pseudoavium; the 'gallinarum group', comprising Enterococcus gallinarum and Enterococcus casseliflavus; and a fourth group, comprising Enterococcus columbae and Enterococcus cecorum. Other described enterococci form individual lines of descent, e.g. Enterococcus sulfureus, Enterococcus saccharolyticus, Enterococcus asini and Enterococcus faecalis. Recently, two novel species, Enterococcus haemoperoxidus and Enterococcus moraviensis (Švec et al., 2001), have been shown to be phylogenetically closely related to Enterococcus faecalis. However, 16S rRNA gene sequence similarities between enterococcal species are mostly high and exceed the generally accepted value of $97 \%$ for species differentiation. For this reason, at the genetic level, only the percentage of DNA-DNA hybridization can clearly indicate their species identity.

Phenotypically, there are no definite characteristics that distinguish the enterococci unequivocally from the other Gram-positive, catalase-negative, coccus-shaped bacteria or within the genus, at the species level. The ability to grow at 10 and $45^{\circ} \mathrm{C}$, in $6.5 \% \mathrm{NaCl}$, at $\mathrm{pH} 9.6$ and on selective 
media can also be possessed by some non-enterococcal species, while these criteria can exclude several novel enterococcal species, such as Enterococcus columbae, which fails to grow in $6.5 \% \mathrm{NaCl}$ (Devriese et al., 1990), or Enterococcus haemoperoxidus (Švec et al., 2001), which shows a clear positive catalase reaction.

For these reasons, a polyphasic approach is desirable for correctly identifying 'unusual' enterococcal strains. Today, some aspects of the taxonomic and genotypic diversity within the genus Enterococcus can also be further investigated through the use of recently developed molecular techniques, such as intergenic ribosomal PCR, randomly amplified polymorphic DNA and PFGE (Angeletti et al., 2001; Naïmi et al., 1997; Poyart et al., 2000; Quednau et al., 1998).

Recently, during a study on the natural bacterial population obtained from raw cows' milk used in the production of artisanal Italian cheeses (Fortina et al., 2003), we isolated some atypical Enterococcus strains that seemed to represent a novel species of Enterococcus. In the present paper, we describe a polyphasic study of a collection of seven isolates: five originated from Toma piemontese cheese and two were from Robiola piemontese cheese. The results demonstrated that the strains represent a novel species, for which the name Enterococcus italicus sp. nov. is proposed.

Strains TP1.5 ${ }^{\mathrm{T}}$, TP1.3, TP2.3, TP1.D and TP3.D were isolated from Toma piemontese cheese, while strains RP1 and RP4 were isolated from Robiola piemontese cheese. They were routinely maintained at $4{ }^{\circ} \mathrm{C}$ after growth at $37^{\circ} \mathrm{C}$ for $18 \mathrm{~h}$ in $\mathrm{M} 17$ glucose broth or agar (Difco). On this agar, colonies appeared circular and smooth, with entire margins; after 3 days growth, they were $1 \mathrm{~mm}$ in diameter.

Cell morphology was studied using phase-contrast microscopy. Gram staining was done as described by Salle (1961). Growth was checked on kanamycin/aesculin/azide agar (Merck), blood agar and skimmed-milk medium. Sugarfermentation patterns were determined by using a microtitre plate assay and a basal M17 medium containing chlorophenol red as indicator and the desired filtersterilized carbohydrate at a final concentration of $0.2 \%$ $(\mathrm{w} / \mathrm{v})$. The reproducibility was verified by repeated analyses. A pH-dependent change in the indicator was documented for up to 5 days. Only definitive turnovers were rated as positive. Biochemical tests were also performed using API galleries $50 \mathrm{CH}$ and 20 STREP (bioMérieux) according to the manufacturer's instructions. Susceptibility to antibiotics was evaluated after overnight growth at $37^{\circ} \mathrm{C}$ in M17 glucose broth containing different concentrations of antibiotic and using $10^{5}$ cells $\mathrm{ml}^{-1}$ as the initial inoculum.

DNA was isolated and purified as described previously (Fortina et al., 2001a). The DNA base composition was determined in $0 \cdot 1 \times$ SSC buffer $(1 \times$ SSC is $0.15 \mathrm{~mol}$ $\mathrm{NaCl} l^{-1}$ plus $0 \cdot 015$ mol sodium citrate $1^{-1}$ ) by using the thermal denaturation method described by Marmur \& Doty
(1962) and the equation of Owen \& Hill (1979). DNA from Escherichia coli strain B (Sigma) was used as the internal standard. The extent of DNA reassociation was determined as previously described (Fortina et al., 2001b) by using the optical renaturation rates method with a model Response spectrophotometer equipped with an Advance Kinetics Graphic version 1.3 thermoprogrammer (CIBA-Corning Diagnostics). For all samples tested, the reaction was carried out under optimal conditions $\left(25^{\circ} \mathrm{C}\right.$ below the melting temperature) in $5 \times$ SSC, containing $20 \%(\mathrm{v} / \mathrm{v}) \mathrm{DMSO}$. The equation of Seidler \& Mandel (1971) was used to calculate the extent of DNA-DNA reassociation.

Genomic DNA extraction, PCR-mediated amplification of the 16S rRNA gene and sequencing of the PCR products were performed as described previously (Fortina et al., 2003). Pairwise alignment similarities were calculated using the Ribosomal Database Project service (Maidak et al., 2001). Phylogenetic reconstructions were done by using the TREECON software (version 1.3b) (Van de Peer \& De Wachter, 1994) and the model of Jukes \& Cantor (1969). Amplification of the 16S-23S rRNA gene intergenic transcribed spacer region was performed as previously described (Fortina et al., 2003), employing the primers G1 (5'-GAAGTCGTAACAAGG-3') and L1 (5'-CAAGGCATCCACCGT-3') (Jensen et al., 1993). Following amplification, the reaction mixtures were electrophoresed in $3 \%$ agarose gel in TAE buffer $(40 \mathrm{mM}$ Tris/acetate, $1 \mathrm{mM}$ EDTA, $\mathrm{pH} \mathrm{8)}$ at $100 \mathrm{~V}$ for $2 \mathrm{~h}$, before staining with ethidium bromide. A DNA ladder (50 bp; Amersham Pharmacia Biotech) was used as the molecular size marker.

Analysis of fatty acid methyl esters was performed by GC using the Microbial Identification System (MIDI) at the DSMZ (Braunschweig, Germany).

The strains were Gram-positive with spherical or ovoid cells that occurred in pairs and short chains, catalase-negative, non-motile and non-endospore-forming. The strains did not grow on kanamycin/aesculin/azide agar, showed $\alpha$ haemolysis on blood agar and were able to grow in skimmed-milk medium, in which they caused clotting within $48 \mathrm{~h}$ incubation. All of the strains were susceptible to vancomycin. Growth was enhanced slightly by cultivation in a $5 \% \mathrm{CO}_{2}$ atmosphere and was more abundant at $37^{\circ} \mathrm{C}$ in comparison with 30 or $25^{\circ} \mathrm{C}$. Growth occurred at pH 9.6 and at $42^{\circ} \mathrm{C}$, but was reduced at $10^{\circ} \mathrm{C}$. The ability to grow at $45^{\circ} \mathrm{C}$ was variable among the strains tested. The novel isolates failed to grow in M17 broth containing $6.5 \% \mathrm{NaCl}$, as for strains of Enterococcus cecorum (Devriese et al., 1983) and Enterococcus columbae (Devriese et al., 1990). The ability to grow in $6 \% \mathrm{NaCl}$ was possessed only by the type strain, TP1.5 $5^{\mathrm{T}}$, while all isolates grew in $5 \% \mathrm{NaCl}$.

The almost complete 16S rRNA gene sequence (1396 bp) of TP $1.5^{\mathrm{T}}$ had the highest similarity to $16 \mathrm{~S}$ rRNA gene sequences of enterococci: pairwise sequence alignments indicated that the closest relatives of strain $\mathrm{TP} 1.5^{\mathrm{T}}$ are Enterococcus saccharolyticus and Enterococcus sulfureus 


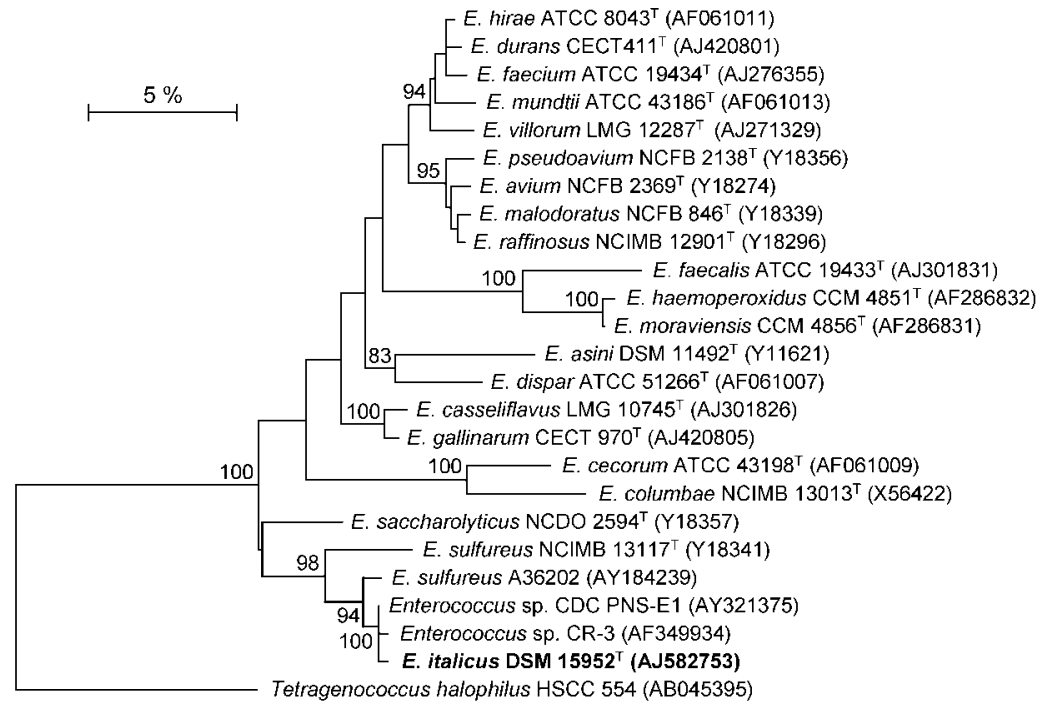

Fig. 1. Phylogenetic tree based on $16 \mathrm{~S}$ rRNA gene sequences available from the GenBank/EMBL/DDBJ database (accession numbers in parentheses), showing the relationship between Enterococcus italicus sp. nov. and other enterococci. The sequence of the 16S rRNA gene of Tetragenococcus halophilus was used as an outgroup. Sequences were aligned using the Ribosomal Database Project service. A neighbourjoining tree was constructed using TREECON software (version 1.3b) and includes bootstrap probability values (\%) at the branchpoints (500 tree replications).
(96.7\%) and Enterococcus gallinarum (95.4\%). Lower sequence similarities $(<95 \%)$ were found with other described species of the genus Enterococcus. The 16S rRNA genes of the species of the genera Melissococcus and Tetragenococcus, for which a close relationship with the enterococcal strains has been previously demonstrated, exhibited 90.4 and $88.8 \%$ sequence identity, respectively, with the $16 \mathrm{~S}$ rRNA gene sequence of strain TP $1.5^{\mathrm{T}}$. Strain $\mathrm{TP} 1.5^{\mathrm{T}}$ was more distantly related to the streptococcal and lactococcal species tested ( $<84 \%$ sequence identity). A tree depicting the phylogenetic affinity of strain TP $1.5^{\mathrm{T}}$ with other enterococci is shown in Fig. 1. It should be noted that the $16 \mathrm{~S}$ rRNA gene sequence of strain TP $1.5^{\mathrm{T}}$ showed $99 \%$ similarity to those of two unidentified strains (accession nos AF349934 and AY321375) and of a strain deposited as Enterococcus sulfureus (accession no. AY184239). These strains, isolated from an artisanal Sicilian cheese, from human clinical specimens and from a fermented maize beverage, respectively, could belong to Enterococcus italicus sp. nov., indicating the possibility that it occurs in other sources. Whether or not these enterococci belong to Enterococcus italicus remains to be determined.

Similarly, DNA-DNA hybridization results (Supplementary Table A in IJSEM Online) for the seven novel strains and the type strain of the seven reference Enterococcus species tested confirmed the species identity of the isolates. These DNA-DNA relatedness values clearly differentiated the strains from the phylogenetically closest species, Enterococcus saccharolyticus, Enterococcus sulfureus and Enterococcus gallinarum, and revealed high levels of similarity between strains.

PCR amplification of the intergenic transcribed spacer between the $16 \mathrm{~S}$ and $23 \mathrm{~S}$ rRNA genes produced an amplification profile characteristic of the novel enterococcal species. This fingerprint pattern showed genetic homogeneity in the cheese isolates and separated them from all enterococcal species included in this study by the presence of three major bands with approximate sizes of 400, 380 and 300 bp (Fig. 2).

The fatty acid profile of strain $\mathrm{TP} 1.5^{\mathrm{T}}$ was compared with those of its closest relatives, Enterococcus saccharolyticus and Enterococcus sulfureus. Qualitatively, all three strains showed roughly the same fatty acid pattern, but there were significant quantitative differences. The major nonhydroxylated long-chain fatty acids of strain $\mathrm{TP} 1.5^{\mathrm{T}}$ were $\mathrm{C}_{16: 0}(27 \cdot 9 \%)$ and $\mathrm{C}_{18: 1} \omega 7 c(60 \cdot 6 \%) ; \mathrm{C}_{19: 0}$ cyclo $\omega 8 c$ was present in small amounts $(2 \cdot 5 \%)$. Enterococcus sulfureus produced significantly smaller amounts of $\mathrm{C}_{18: 1} \omega 7 c$ and

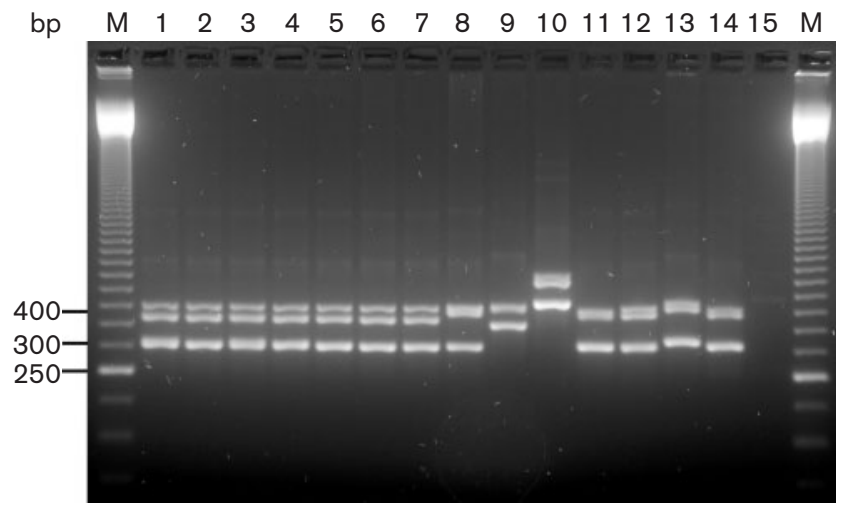

Fig. 2. Intergenic transcribed spacer-PCR profiles of Enterococcus italicus sp. nov. and other enterococcal species. Lanes: 1-7, Enterococcus italicus strains; 8, Enterococcus faecalis NCDO 588; 9, Enterococcus durans NCDO 595; 10 , Enterococcus faecium ATCC $19434^{\top} ; 11$, Enterococcus sulfureus DSM $6905^{\top} ; 12$, Enterococcus gallinarum DSM $20628^{\top}$; 13, Enterococcus avium DSM 20679 ${ }^{\top}$; 14, Enterococcus saccharolyticus DSM $20726^{\top} ; 15$, negative control; M, 50base-pair ladder (Amersham Pharmacia Biotech). 
very large amounts of $\mathrm{C}_{19: 0}$ cyclo $\omega 8$. Enterococcus saccharolyticus showed more balanced amounts of $\mathrm{C}_{16: 0}$ and $\mathrm{C}_{18: 1} \omega 7 c, \mathrm{C}_{19: 0}$ cyclo $\omega 8 c$ was not detectable (Supplementary Table B in IJSEM Online).

In complete agreement with the phylogenetic and genotypic examinations described above, the phenotypic studies clearly separated all the novel strains from the other reference species. Indeed, the novel species can be readily distinguished from the other enterococci by using a combination of physiological and biochemical tests (Table 1). In particular, utilization of ribose confirms the separateness of the cheese isolates from all tested enterococcal species. Enterococcus italicus can also be differentiated from its closest relatives, Enterococcus saccharolyticus and Enterococcus sulfureus, by its inability to acidify L-arabinose, melezitose, melibiose and raffinose.

The results of the present study allowed us to assign the strains tested to a novel species, for which we propose the name Enterococcus italicus sp. nov. The 16S rRNA gene sequence and DNA-DNA hybridization analyses indicate that all of the cheese isolates form a homogeneous group

Table 1. Biochemical tests useful for the differentiation of Enterococcus italicus sp. nov. from other enterococci

Taxa: 1, Enterococcus italicus; 2, Enterococcus saccharolyticus; 3, Enterococcus sulfureus; 4, Enterococcus faecalis; 5, the Enterococcus faecium group; 6, the Enterococcus avium group; 7 , the Enterococcus gallinarun group; 8, the Enterococcus cecorum group. Data for taxa other than Enterococcus italicus were obtained from Collins et al. (1984), Farrow et al. (1984), Martinez-Murcia \& Collins (1991), Devriese et al. (1993), Vancanneyt et al. (2001) and De Graef et al. (2003). +, Positive; D, different or variable; $\mathrm{D}+$, usually positive; $\mathrm{D}-$, usually negative; - , negative; $\mathrm{W}$, weak reaction; ND, not determined.

\begin{tabular}{|lccccccccc|}
\hline Characteristic & $\mathbf{1}$ & $\mathbf{2}$ & $\mathbf{3}$ & $\mathbf{4}$ & $\mathbf{5}$ & $\mathbf{6}$ & $\mathbf{7}$ & $\mathbf{8}$ \\
\hline Pigment production & - & - & + & - & - & $(+)^{a_{*}}$ & - & $\mathrm{D}^{b}$ & - \\
Growth in $6.5 \% \mathrm{NaCl}$ & - & + & + & + & + & + & + & - \\
Growth at $10{ }^{\circ} \mathrm{C}$ & $\mathrm{W}$ & + & + & + & + & $\mathrm{D}+$ & + & $\mathrm{D}-$ \\
Acid production from: & & & & & & & & \\
$\quad$ L-Arabinose & - & - & - & - & $\mathrm{D}^{c}$ & $\mathrm{D}^{d}$ & + & $\mathrm{D}+{ }^{e}$ \\
Melezitose & - & + & + & $\mathrm{D}+$ & - & $\mathrm{D}^{d}$ & - & $\mathrm{D}$ \\
Melibiose & - & + & + & - & $\mathrm{D}+{ }^{f}$ & $\mathrm{D}$ & + & + \\
Raffinose & - & + & + & - & $\mathrm{D}-$ & $\mathrm{D}^{g}$ & $\mathrm{D}$ & + \\
Ribose & - & + & + & + & + & + & + & + \\
Sorbitol & $\mathrm{D}$ & + & - & $\mathrm{D}+$ & $-(+)^{f}$ & + & $\mathrm{D}-$ & $\mathrm{D}$ \\
\hline
\end{tabular}

${ }^{\star}$ Discrepant results are indicated by: $a$, positive in Enterococcus mundtii; $b$, positive in Enterococcus casseliflavus; $c$, positive in Enterococcus faecium, Enterococcus mundtii and Enterococcus canis; $d$, positive in Enterococcus avium and Enterococcus raffinosus; $e$, negative in Enterococcus cecorum; $f$, positive in Enterococcus canis; $g$, negative in Enterococcus avium and Enterococcus pseudoavium. that can be differentiated from other Enterococcus species. Further support for the distinctiveness of the novel species comes from phenotypic evidence.

\section{Description of Enterococcus italicus sp. nov.}

Enterococcus italicus (i.ta'li.cus. L. masc. adj. italicus from Italy, where the bacterium was first isolated).

Cells are facultatively anaerobic, non-motile, non-sporeforming, catalase-negative, non-pigmented, Gram-positive cocci that occur in pairs or short chains. Colonies are whitish-grey, circular and smooth, with entire margins; $1 \mathrm{~mm}$ in diameter after 3 days growth on M17 glucose agar. Growth is enhanced slightly by cultivation in a $5 \%$ $\mathrm{CO}_{2}$ atmosphere and is optimal at $37^{\circ} \mathrm{C}$. Growth occurs at $42^{\circ} \mathrm{C}$, but is weak at $10^{\circ} \mathrm{C}$. The ability to grow at $45^{\circ} \mathrm{C}$ is variable among the strains. Strains grow at $\mathrm{pH} 9 \cdot 6$ and in $5 \% \mathrm{NaCl}$. A few strains are positive for growth in $6 \%$ $\mathrm{NaCl}$; no growth is seen in $6.5 \% \mathrm{NaCl}$. The strains do not grow on kanamycin/aesculin/azide agar, show $\alpha$-haemolysis on blood agar and are able to grow in skimmed-milk medium, where they cause clotting within $48 \mathrm{~h}$ incubation. All strains are susceptible to vancomycin. Homofermentative, producing lactic acid and no gas. Acid is produced from galactose, D-glucose, D-fructose, D-mannose, methyl $\alpha$-D-glucoside (often delayed), $N$-acetylglucosamine, aesculin, salicin, maltose, lactose, sucrose, trehalose and starch. Weak reactions can occur on cellobiose. Acid is not produced from glycerol, erythritol, D-arabinose, L-arabinose, ribose, D-xylose, L-xylose, adonitol, methyl $\beta$-xyloside, L-sorbose, rhamnose, dulcitol, inositol, methyl $\alpha$-D-mannoside, amygdalin, melibiose, inulin, melezitose, D-raffinose, glycogen, xylitol, D-turanose, D-lyxose, D-fucose, L-fucose, D-arabitol, L-arabitol, gluconate, 2-ketogluconate or 5ketogluconate. Strain-dependent reactions are observed with mannitol (4/7 strains), $\beta$-gentiobiose (3/7 strains), D-tagatose (3/7 strains), arbutin (3/7 strains) and sorbitol (5/7 strains). Positive results are obtained in API tests for acetoin production, aesculin hydrolysis, pyrrolidonyl arylamidase and leucine arylamidase. Strains are negative for hippurate hydrolysis, $\alpha$-galactosidase, $\beta$-glucuronidase, $\beta$-galactosidase, alkaline phosphatase and arginine dihydrolase. The DNA G+C content ranges from $39 \cdot 9$ to $41 \cdot 1 \mathrm{~mol} \%$, as determined by melting temperature. The strains form a distinct relatedness group, as determined by DNA-DNA hybridization. The strains can also be differentiated from the other species of Enterococcus by their unique intergenic transcribed spacer profile and the sequence of their $16 \mathrm{~S}$ rRNA genes.

Strains were isolated from dairy products in Piedmont, Italy. The type strain is DSM $15952^{\mathrm{T}}\left(=\mathrm{LMG} 22039^{\mathrm{T}}\right)$

\section{Acknowledgements}

This study was performed within a research project set-up and was supported by the Ministero delle Politiche Agricole e Forestali (MIPAF, Rome, Italy) (paper no. 20). 


\section{References}

Angeletti, S., Lorino, G., Gherardi, G., Battistoni, F., De Cesaris, M. \& Dicuonzo, G. (2001). Routine molecular identification of enterococci by gene-specific PCR and $16 \mathrm{~S}$ ribosomal DNA sequencing. J Clin Microbiol 39, 794-797.

Collins, M. D., Jones, D., Farrow, J. A. E., Kilpper-Balz, R. \& Schleifer, K. H. (1984). Enterococcus avium nom. rev., comb. nov.; E. casseliflavus nom. rev., comb. nov.; E. durans nom. rev., comb. nov.; E. gallinarum comb. nov.; and E. malodoratus sp. nov. Int J Syst Bacteriol 34, 220-223.

De Graef, E. M., Devriese, L. A., Vancanneyt, M., Baele, M., Collins, M. D., Lefebvre, K., Swings, J. \& Haesebrouck, F. (2003). Description of Enterococcus canis sp. nov. from dogs and reclassification of Enterococcus porcinus Teixeira et al. 2001 as a junior synonym of Enterococcus villorum Vancanneyt et al. 2001. Int J Syst Evol Microbiol 53, 1069-1074.

Devriese, L. A. \& Pot, B. (1995). The genus Enterococcus. In The Genera of Lactic Acid Bacteria, pp. 327-367. Edited by B. J. B. Wood \& W. H. Holzapfel. London: Blackie Academic \& Professional.

Devriese, L. A., Dutta, G. N., Farrow, J. A. E., Van De Kerckhove, A. \& Phillips, B. A. (1983). Streptococcus cecorum, a new species isolated from chickens. Int J Syst Bacteriol 33, 772-776.

Devriese, L. A., Ceyssens, K., Rodrigues, U. M. \& Collins, M. D. (1990). Enterococcus columbae, a species from pigeon intestines. FEMS Microbiol Lett 71, 247-252.

Devriese, L. A., Pot, B. \& Collins, M. D. (1993). Phenotypic identification of the genus Enterococcus and differentiation of phylogenetically distinct enterococcal species and species groups. J Appl Bacteriol 75, 399-408.

Ennahar, S. \& Deschamps, S. (2000). Anti-Listeria effect of enterocin A, produced by cheese-isolated Enterococcus faecium EFM01, relative to other bacteriocins from lactic acid bacteria. J Appl Microbiol 88, 449-457.

Farrow, J. A. E., Kruze, J., Phillips, B. A., Bramley, A. J. \& Collins, M. D. (1984). Taxonomic studies on Streptococcus bovis and Streptococcus equinus: description of Streptococcus alactolyticus sp. nov. and Streptococcus saccharolyticus sp. nov. Syst Appl Microbiol 5, 467-482.

Fortina, M. G., Ricci, G., Mora, D., Parini, C. \& Manachini, P. L. (2001a). Specific identification of Lactobacillus helveticus by PCR with pepC, pepN and htrA targeted primers. FEMS Microbiol Lett 198, 85-89.

Fortina, M. G., Pukall, R., Schumann, P., Mora, D., Parini, C., Manachini, P. L. \& Stackebrandt, E. (2001b). Ureibacillus gen. nov., a new genus to accommodate Bacillus thermosphaericus (Andersson et al. 1995), emendation of Ureibacillus thermosphaericus and description of Ureibacillus terrenus sp. nov. Int J Syst Evol Microbiol 51, 447-455.

Fortina, M. G., Ricci, G., Acquati, A., Zeppa, G., Gandini, A. \& Manachini, P. L. (2003). Genetic characterization of some lactic acid bacteria occurring in an artisanal protected denomination origin (PDO) Italian cheese, the Toma piemontese. Food Microbiol 20, 397-404.

Franz, C. M. A. P., Holzapfel, W. H. \& Stiles, M. E. (1999). Enterococci at the crossroads of food safety? Int J Food Microbiol 47, $1-24$.

Giraffa, G. (2002). Enterococci from foods. FEMS Microbiol Rev 26, 163-171.

Giraffa, G., Carminati, D. \& Neviani, E. (1997). Enterococci isolated from dairy products: a review of risks and potential technological use. J Food Prot 60, 732-738.
Jensen, M. A., Webster, J. A. \& Strauss, N. (1993). Rapid identification of bacteria on the basis of polymerase chain reactionamplified ribosomal DNA spacer polymorphisms. Appl Environ Microbiol 59, 945-952.

Jukes, T. H. \& Cantor, C. R. (1969). Evolution of protein molecules. In Mammalian Protein Metabolism, pp. 21-132. Edited by H. N. Munro. New York: Academic Press.

Maidak, B. L., Cole, J. R., Lilburn, T. G. \& 7 other authors (2001). The RDP-II ribosomal database project. Nucleic Acids Res 29, 173-174.

Marmur, J. \& Doty, P. (1962). Determination of the base composition of deoxyribonucleic acid from its thermal denaturation temperature. J Mol Biol 5, 109-118.

Martinez-Murcia, A. J. \& Collins, M. D. (1991). Enterococcus sulfureus, a new yellow-pigmented Enterococcus species. FEMS Microbiol Lett 80, 69-74.

Morrison, D., Woodford, N. \& Cookson, B. (1997). Enterococci as emerging pathogens of humans. Soc Appl Bacteriol Symp Ser 26, 89S-99S.

Naïmi, A., Beck, G. \& Branlant, C. (1997). Primary and secondary structures of rRNA spacer regions in enterococci. Microbiology 143, 823-834.

Owen, R. J. \& Hill, L. R. (1979). The estimation of base composition, base pairing and genome size of bacterial deoxyribonucleic acid. In Identification Methods for Microbiologists, pp. 277-296. Edited by F. A. Skinner \& D. W. Lovelock. London: Academic Press.

Poyart, C., Quesnes, G. \& Trieu-Cuot, P. (2000). Sequencing the gene encoding manganese-dependent superoxide dismutase for rapid species identification of enterococci. J Clin Microbiol 38, 415-418.

Quednau, M., Ahrné, S., Petersson, A. C. \& Molin, G. (1998). Identification of clinically important species of Enterococcus within 1 day with randomly amplified polymorphic DNA (RAPD). Curr Microbiol 36, 332-336.

Robredo, B., Singh, K. V., Baquero, F., Murray, B. E. \& Torres, C. (2000). Vancomycin-resistant enterococci isolated from animals and food. Int J Food Microbiol 54, 197-204.

Salle, A. J. (1961). Laboratory Manual on Fundamental Principles of Bacteriology. New York: McGraw-Hill.

Schleifer, K. H. \& Kilpper-Bälz, R. (1984). Transfer of Streptococcus faecalis and Streptococcus faecium to the genus Enterococcus nom. rev. as Enterococcus faecalis comb. nov. and Enterococcus faecium comb. nov. Int J Syst Bacteriol 34, 31-34.

Seidler, R. J. \& Mandel, M. (1971). Quantitative aspects of deoxyribonucleic acid renaturation: base composition, state of chromosome replication, and polynucleotide homologies. $J$ Bacteriol 106, 608-614.

Stiles, M. E. \& Holzapfel, W. H. (1997). Lactic acid bacteria of foods and their current taxonomy. Int J Food Microbiol 36, 1-29.

Švec, P., Devriese, L. A., Sedláček, I., Baele, M., Vancanneyt, M., Haesebrouck, F., Swing, J. \& Doškař, J. (2001). Enterococcus haemoperoxidus sp. nov. and Enterococcus moraviensis sp. nov., isolated from water. Int J Syst Evol Microbiol 51, 1567-1574.

Vancanneyt, M., Snauwaert, C., Cleenwerck, I. \& 8 other authors (2001). Enterococcus villorum sp. nov., an enteroadherent bacterium associated with diarrhoea in piglets. Int J Syst Evol Microbiol 51, 393-400.

Van de Peer, Y. \& De Wachter, R. (1994). TREECON for Windows: a software package for the construction and drawing of evolutionary trees for the Microsoft Windows environment. Comput Appl Biosci 10, 569-570. 